\title{
The Influence of Industrial Revolution 4.0 on the Competence of STIE Pembangunan Tanjungpinang Students
}

\author{
Tubel Agusven, Helen Tan Sui Hong, Satriadi
}

\begin{abstract}
This study will explain the influence of industrial revolution 4.0 on the competence of STIE Pembangunan Tanjungpinang Students. The workforce needed by the industry today are those are competent in the use of digital technology to create smart factories, such as one of the Internet of Things (IoT). The era of the industrial revolution 4.0 opens the opportunity to all students to acquire expertise in accordance with the latest technological developments. For this reason, it is necessary to carry out an up-skilling program or reskilling of students based on the needs of today's industry because talent is the key or important factor for the success participation in industry 4.0. This study uses participatory qualitative research method, which emphasize the depth of the results of research where researchers are directly involved as research instruments. Data is obtained through literature studies, interviews and direct practice. The results of this study will explain the efforts in preparing and mapping the competence of STIE Development students in the era of industrial revolution 4.0. in creating competent students. This is important if our nation wants to be empowered in the days of the fourth industrial revolution which is all automatic and robotic characterised by the latest technology.
\end{abstract}

\section{Keywords : Industrial Revolution 4.0, Competence, Student}

\section{INTRODUCTION}

Changes in the world are now entering the era of industrial revolution 4.0 or the fourth world industrial revolution where information technology has become the basis of human life. Everything becomes borderless with unlimited (unlimited) use of computing and data power, because it is influenced by the development of massive internet and digital technology as the backbone of the movement and connectivity of humans and machines. This era will also disrupt various human activities, the problem of human resources is one of the important elements in the organization. Human resources play a role in determining the direction and progress of an organization. Director General Ghufron believes that Indonesian universities are able to survive in this era of industrial revolution when implementing 4C. First, the critical thingking, we should be skeptical and critical. "It's useless if it's smart if it's not critical," he said. Second, Creativity, which is able to give birth to new innovations.

Revised Manuscript Received on October15, 2019

* Correspondence Author

Tubel Agusven*, STIE Pembangunan Tanjungpinang, Indonesia. Email: t17abel@gmail.com

Helen Tan Sui Hong, Azman Hashim International Business School, Universiti Teknologi Malaysia, Skudai, Malaysia. Email: tansuihong@utm.my

Satriadi, STIE Pembangunan Tanjungpinang, Indonesia. Email: satriadi456@gmail.com
Furthermore, Communication, especially about science and technology so that the public can be accepted correctly and does not cause misunderstanding. "It's useless for some industries if it's not communicated. No one will understand and know, "he said. Finally, Collaboration, this is the power that can build Indonesia. According to him, Indonesia's weakness is lack of collaboration. We are weak when in groups. Because it requires cooperation and understanding each other. Straubhaar and LaRose (2011) both describe technological change as a revolution experienced by society in their lives due to technological developments. Starting from the community before farming which is characterized by culture of speaking or oral words in which people in the past are grouped and live from hunting and farming. But the shift occurred when found tools for fishing (fishing), collecting wood in the forest (logging), to extracting mining materials (mining) changed the way humans interact. This stage the oral tradition becomes a tradition of reading. The tradition of reading is still very limited only to Catholic clergy and has not yet reached most other communities. The emergence of the industrial revolution also changed the face of the tradition of reading which had previously only been limited to more people who could read ideas or thoughts because of the mass production of the invention of printing machines. Then the shift occurred again when people were able to consume and produce messages by adopting digital technology. This stage signifies a major change in the way humans interact with other humans; because digital technology has created a very interactive media, the internet.

The internet has changed the way humans carry out daily interactions from oral to written interactions. As Straubhaar \& LaRose (2011) say that the internet era is an era of information society where individuals spend more time behind computers and change the form of media into written forms (computer-readable). This written form in interactive media allows for a different understanding of the actual reality. One of the facts is the emergence of a change in individual attitudes and behaviour (Simangunsong, 2011) In today's age the rapid development of increasingly sophisticated technology so that each individual is required to be able to explore all the human resources they have, to be able to support our performance so that very influential on the execution of tasks every day. Even the system of facilities and infrastructure in the organization can continue to develop and continue to be refined over time, so that an organization can develop in accordance with existing human resources. Many experts argue that quality human resources determine whether 
or not an organization is successful with the competencies of each employee.

To form a student figure like that does require a long time and process and efforts that should not stop.

\section{LITERATURE REVIEW}

Gabriel and Pessl (2016) point out that "The main objective of Industry 4.0 is to strengthen and extend the long-term competitiveness of the company by increasing the flexibility and efficiency of production through communication, information and intelligence" (p. 133). This new revolution involves three areas that are very important, such as automation, robotics or the digitization of everything, but the aspect that plays a key role is the internet of things or rather internet of everything (Basl, 2106). It involves the interconnection of several elements in order that organizations are creating intelligent networks along the entire value chain that can be controlled autonomously. These networks help reduce process time, product development time, generate real-time transparency and enable faster, more flexible decisions.

Experts agree that the manual execution processes that are done properly by people skills such as intelligence, creativity, empathy or flexibility will remain vital. The results obtained in an empirical study of production in the future coincide with $60.2 \%$ of the respondents stated that human work will continue to play a very important role in future production; $36.6 \%$ considered human work as a vital role within the organization (Gabriel \& Pessl, 2016). Increased use of care systems means that the qualitative change brought about by Industry 4.0 is likely to be positive for the workforce. Works that are routine will decrease while jobs that require flexible response, problem solving, and personalization will increase (Lorentz et al., 2015).

The term "competency" in English is called "Competencies" or "Competence". The English-Indonesian dictionary defines competence as an ability or skill. In a further development the term competency began to be used by many people in various uses with different perceptions, including the use of human resource management. Spencer and Spencer (in Sudarmanto, 2009) say, competence is a basic characteristic of individual behavior that is associated with effective reference criteria and / or superior performance in work or situation. In other words, competence is the basic foundation of people's characteristics and identifies ways to behave or think, equate situations, and support for a long period of time. Brian (in Sudarmanto, 2009) defines competence as individual knowledge, skills, abilities, or personal characteristics that directly affect job performance.

Armstrong (2004) defines competence as what people carry on a job in the form of different types and levels of behaviour. Murphy (in Sedarmayanti, 2009) defines competency as any proven individual's talent and expertise, can be associated with excellent and effective performance. The low performance that still requires these improvements is assumed because there are several factors that can improve employee performance, including: desire, knowledge and skills, climate, support and appreciation, competence, work ethic, income level, and education level. From every factor that influences employee performance, there are quite important problems to be addressed, among others: lack of ability and skills of employees who still need improvement and training, lack of motivation and support from the leadership, lack of leadership attention in paying attention to the family atmosphere, harmony and welfare of employees, lack of desire of employees to change to be better, and leaders less reward employees, employees often spend work time doing things that are not related to their work, such as: playing online games, Facebook, listening to music, and so on. Basically the ability of individuals to want to be more advanced and developing is all coming from the willingness and desires of individuals to learn a lot, explore all the potential that exists within themselves and especially is self-development through the improvement of knowledge. Because all of that is very supportive in improving performance as one form of embodiment that can be seen clearly a person's ability to do a job.

Many civil servant employees are found, they no longer want to continue their education to the undergraduate level because the reason they are an age factor, there is no free time to study, the ability to learn is no longer able, and also soon to enter the preparation period pension. So that it can be seen that they do not want to develop for career advancement and also especially in improving performance. Aspects that must be done to realize competence, namely hard work and a great desire to want to learn and keep learning without thinking about things that limit us to retreat and do not want to develop, because the knowledge and skills that are owned will bring us to a success. As a form of job responsibility in advancing, crafting, loyalty and creativity should be improved by always thinking positively and eliminating all bad habits such as: procrastinating, lazy to enter the office but should have a willingness to continue to develop. If we often postpone work, lazy in the office and do not have the will to develop it will greatly affect our performance. Therefore, by thinking positively in order to improve performance, crafting, loyalty and creativity can improve performance

\section{METHODE}

In this study using qualitative research methods where this study will emphasize the depth of the results of research where researchers are directly involved as research instruments. Qualitative method is a contextual study that makes humans as instruments, and adapted to a reasonable situation in relation to data collection which is generally qualitative. According to Bogdan and Tylor (in Moleong, 2001) is a research procedure that produces descriptive data in the form of written or oral words from people and observable behaviour. Ardianto (2010) explains that qualitative research is artistic behaviour. The philosophical approach and application of methods within the framework of qualitative research are intended to produce "soft sciences" such as: sociology, anthropology, (communication and public relations, Pen) qualitative researchers believe that "truth" (Truth) is dynamic and can be found only through ingestion towards people in their interactions with social welfare situations (Danim, 2002).

Data collection is done using the method of in-depth interviews (in-depth interviews) and observation. Interview is a recharging tool or proof of information or information obtained previously. 
The interview technique used in qualitative research is in-depth interviews. In-depth interviews are the process of obtaining information for research purposes by way of question and answer face-to-face between interviewers and informants or people interviewed, with or without using an interview guide (guide), where interviewers and informants are involved in social life relatively long (Sutopo 2006). Interview is an effort to collect information by asking a number of questions verbally to be answered verbally as well. The main characteristic of the interview is direct contact with face to face (face to face relationship) between the information seeker (interviewer or hunter informant) with information sources (interviewee). (Sutopo, 2006). Types of interviews include free interviews, guided interviews, and guided free interviews (Sugiyono, 2008). Free interview, ie the interviewer is free to ask anything, but also remembers what data will be collected. Guided interview, which is an interview conducted by the interviewer by bringing a complete and detailed series of questions. Free guided interviews, namely a combination of free interviews and guided interviews.

Lofland and Lofland (Moleong, 2003) state that the main data sources in qualitative research are words and actions as primary data, the rest are additional data. That is, the words and actions of the subject are only a record (information) that does not give any meaning before being categorized and reduced. So the researcher's ability is to capture data, not just digest verbal information but also be able to uncover behind the respondent's nonverbal actions or language. Data can be in the form of oral, written, action, or other data obtained from information sources. Researchers must consider the four measures suggested by Miles \& Huberman (1984) (in Creswell, 1994); background (where the research will take place), the perpetrator (the person to be observed or interviewed), the event (what will be observed or observed), and the process (the nature of the incident carried out by the perpetrator). In this study, the technique used by researchers is the technique of collecting data in deep interviews. Observation is a technique of data collection, where researchers make observations directly to the object of research to look closely at the activities carried out (Riduan, 2004).

\section{RESULT AND DISCUSSION}

Kunandar (2007: 41) said that a person's competence is divided into 5 (five) parts, including: first, intellectual competence, namely the various sets of knowledge that exist in the individual that is needed to support performance; secondly, physical competence, which is a set of physical abilities needed for carrying out the task; third, personal competence, which is a set of behaviours related to the ability of individuals to manifest themselves, self-transformation, self-identity and self-understanding; fourth, social competence, which is a certain set of behaviours that is the basis of self-understanding as an inseparable part of the social environment; and fifth, spiritual competence, namely understanding, comprehension and practice of religious rules. Still regarding the competency category or classification, Talim (2003: 7) says competence can include aspects of knowledge, skills, attitudes and behaviour of a person. In a broad sense, this competency will be related to organizational strategy and understanding of this competency can be combined with basic skills (soft skills), standard skills (hard skills), social skills (social skills), and mental skills (mental skills). Standard skills (hard skills reflect human resource knowledge and physical skills, soft skills show intuition, human resource sensitivity; social skills show skills in human resource social relations, mental skills show mental resilience of human resource. the development of human resource management, currently being talked about how to manage competency-based human resource

Dharma (2002: 38) said, a competency can be obtained (competency acquisition process) in various ways, including: first, through recognition (recognition). A simulation or case study that gives participants the opportunity to recognize one or more competencies that can predict high-performance individuals in their work so that someone can walk from the experience of the simulation. Second, through understanding (understanding). Case instructions include behavioral modeling of what competencies are and how they are applied. Third, through assessment (assessment). Feedback to participants about how much competency a participant has (comparing participant scores). This method can motivate participants to learn competencies so that they are aware of the relationship between actual performance and ideal performance. Fourth, through feedback. An exercise in which participants can practice competence and get feedback on how participants can carry out certain jobs compared to someone who is performing high. Fifth, through job applications in order to be able to use competencies in real life.

In the Industrial Revolution 4.0 era, these skills included the ability to solve complex problems, critical thinking, creative, human management, the ability to coordinate, as well as having emotional intelligence, skills in giving judgment and making decisions, service oriented, possessing negotiation skills, and cognitive flexibility. In terms of gaining competence and developing it, a student can also obtain it by other methods, namely through education and training both formal and informal. According to Smith (2000:2) training is a planned process to modify attitude, knowledge, skill behavior through learning experience to achieve effective performance in activity or range of activities.

Education and training for students contributes to increasing productivity, effectiveness and efficiency in the learning process. Education and training for students must be provided regularly so that each student is maintained his competence to improve performance. Therefore this training program must receive attention through the planning needs of each student. Rivai (2009:213) states that training is usually focused on efforts to improve performance of employees / employees through the provision of learning special skills or helping them correct weaknesses in their performance. But the training here is given to develop each student's expertise so that it can be directly used in the work they will do in the future. Through training, all efforts are made in order to better improve the competencies of students in carrying out their current tasks. 

necessary and urgent, because competence provides great benefits for a student to improve his performance on campus. There are several competency benefits for students including:

1. Predictors of student success. An accurate competency model will be able to determine precisely what knowledge and skills are needed to succeed in a job. If someone has the competencies required then he can be predicted to be successful.

2. Become a reliable student. If a student has succeeded in determining what competencies are needed, then the student can easily become a reliable person in their field.

3. Basis for student assessment and development. Accurate identification of competencies can also be used as a benchmark for one's abilities. Thus, based on this competency system can be known whether someone has how to develop it, with training and coaching

The most mentioned competency student was big data/data analytics competency. "I think it is about all different kind of data, also video data, images, all ERP data, structured data and unstructured data like Facebook etc." "So to use anonymized big data and volume data and data traffic to predict macro business events rather than micro." The participants see this as the next big thing and believe that for succeeding in Industrial Revolution 4.0, a combination of big data competency with sensors and mobile technology as well as predictive maintenance and machine learning will be very important.

The next most mentioned competency is process know-how and process management competency. De facto, processes are in the focus of Industrial Revolution 4.0, with automation playing an important role. The participants also underlined that business model understanding and entrepreneurship will play a special role in Industrial Revolution 4.0 since this will transform business models. The employees of tomorrow should be prepared to use the technological advances as an advantage and adapt in a fast changing world.

The student also stressed that interdisciplinary competency will play a new role in Industrial Revolution 4.0. An accountant or manager will have to collaborate with the $d$ IT specialists in order to achieve results in the interconnected environment that we will face. The domain or analytical oriented competencies like IT were also important in the discussion. The more technical people they should know afterwards how to create systems." Lastly the student also mentioned further behavioral competencies like customer orientation, decision making, communication, innovating, legal, ethics, and teamwork. "I do not need to understand the whole technical background, but I need to be able to make decisions." "...we should offer group work, so that the participants learn to communicate and work in teams".

In our research, most of the defined competencies are not new, however the presented specific combination of competencies for Industrial Revolution 4.0 is new and makes a contribution to research. Overall, our research emphasizes the importance of student in STIE Pembangunan Tanjungpinang competencies to successfully get through the transformation towards Industrial Revolution 4.0. The results of the literature review and interview delivered mostly
The need for competence is ultimately very

behavioral competencies and only a small part of the competencies represented domain related knowledge. This is also a new aspect with regards to competency building and underlines the changes that Industrial Revolution 4.0 will bring to the way we work. Job vacancies in today's economy often focus on a list of domain knowledge and comprise only some very generic behavioral competencies, like teamwork or independently working. The same situation is presented if we analyze university lectures and curricula. Their focus often is on teaching the students' domain knowledge. The training of further competencies still often is limited to teamwork situations or presentations to be held. These examples show that domain knowledge are the focus of today's economy, while I4.0 will turn around the work environment. Behavioral competencies will be the most important behavioral competencies will be the most important competencies that student should bring. Therefore, research should focus on analyzing how the competency profile of today's student as well as of students could be adapted for Industrial Revolution 4.0. This could include the definition of requirements for curricula and training programs for Industrial Revolution 4.0. Conceptualizing and defining learning strategies and curricula for Industrial Revolution 4.0 might be another interesting topic for research.

If we consider today's economy and disciplines, there is a clear separation between the competencies that student from different disciplines should bring. If, for instance, we mention accountant, everyone recalls a certain job profile and competency set in their mind that is completely different from the profile that one would recall if we mentioned Economic. Our study reveals that in the future the competency sets that different disciplines should bring will be very similar and will differentiate only in some aspects of domain knowledge. This would be a further point where research could offer teaching methods for interdisciplinary teaching.

Our literature review also showed that research on Industrial Revolution 4.0 competencies is rather scarce. The analyzed learning mostly underline that the work environment will change, however no concrete vision or competency models were proposed. With our learning we make an initial contribution that could be further expanded for other professions that require higher education.

This work has practical implications as well. The proposed competency model could be used in practice by companies and universities. Companies could use the model to define job profiles for Industrial Revolution 4.0 vacancies. It cannot be expected that one employee will bring all the competencies included in the model, however by combining some of them depending on the position, different profiles can be described. The results can also be used in competency-based curricula designing.

Although there are limitations to our study, we believe that it can serve as a foundation for further research. Our analysis was based on a literature review as well as four students. The literature search was limited to the databases, where access by our university, is provided. We acknowledge that further research in the area of Industrial Revolution 4.0 competencies is required to study further aspects of 
competencies as well as define how the model could be applied in practice. Especially a definition of a competency profile for a certain job description, e.g. which competencies of the model should an accountant bring, could be a further interesting point for research and practice..

\section{CONCLUSION}

A conclusion section is not required. Although a conclusion may review the main points of the paper, do not replicate the abstract as the conclusion. A conclusion might elaborate on the importance of the work or suggest applications and extensions.

\section{ACKNOWLEDGMENT}

This research was supported/partially supported by STIE Pembangunan \& UTM who provided insight and expertise that greatly assisted the research, although they may not agree with all of the interpretations/conclusions of this paper.

\section{REFERENCES}

1. Afrianto. Being a Professional Teacher in the Era of Industrial Revolution 4.0: Opportunities, Challenges and Strategies for Innovative Classroom Practices Afrianto Faculty of Teachers Training and Education (FKIP), Universita. English Lang Teach Res. 2018;2(1):1-13.

2. Aida Aryani S, Norhayati H. Industrial Revolution 4 . 0 and Education Manag Acad Res Soc [Internet]. 2018;8(9):314-9. Available from http://dx.doi.org/10.6007/IJARBSS/v8-i9/4593\%0Ahttp://hrmars.com/ index.php/pages/detail/publication-ethics

3. Azmi AN, Noordin MK, Kamin Y, Nabil A, Nasir M. Towards Industrial Revolution 4.0: Employers' Expectations on Fresh Engineering Graduates. Int J Eng Technol [Internet]. 2018;(December):267-72. Available from: www.miti.gov.my

4. Díaz Bermudez M, Flores Juárez B. Competencies to adopt Industry 4 . 0 for operations management personnel at automotive parts suppliers in Nuevo Leon. Proc Int Conf Ind Eng Oper Manag Bogota, Volombia [Internet]. 2017;736-47. Available from http://ieomsociety.org/bogota2017/papers/117.pdf

5. Fitsilis P, Sc TPM. Industry 4 . 0 : Required personnel competences. 2018;133(3):4.

6. Harto K. Tantangan Dosen Ptki Di Era Industri 4.0. J Tatsqif. 2018;16(1):1-15.

7. Helaluddin, Wijaya H. Pengembangan Kompetensi Pendidik Di Perguruan Tinggi Dalam Menyonsong Era Revolusi Industri 4.0. Pros Semin Nas Pangan, Teknol dan Entrep [Internet]. 2019;1-7. Available from: https://doi.org/10.31219/osf.io/3mbs4

8. Mintasih D. Mengembangkan Literasi Informasi Melalui Belajar Berbasis Kehidupan Terintegrasi PBL Untuk Menyiapkan Calon Pendidik Dalam Menghadapi Era Revolusi Industri 4.0. ELEMENTARY. 2018;6(2):271-90

9. Nurkholis MA, Badawi. Profesionalisme Guru di Era Revolusi Industri 4.0. Pros Semin Nas Pendidik Progr Pascasarj Univ PGRI Madiun 12 Januari 2019. 2019;491-8.

10. Prifti L, Knigge M, Kienegger H, Krcmar H. A Competency Model for \&quot;Industrie 4.0\&quot; Employees. Wirtschaftsinformatik [Internet]. 2017;46-60. Available from: https://www.wi2017.ch/images/wi2017-0262.pdf

11. Rohida L. Pengaruh Era Revolusi Industri 4.0 terhadap Kompetensi Sumber Daya Manusia. J Manaj dan Bisnis Indones. 2018;6(1):114-36.

12. Sihite M. Peran Kompetensi Dalam Mewujudkan Sumber Daya Manusia Yang Berdaya Saing Tinggi di Era Revolusi Industri 4.0: Suatu Tinjauan Konseptual. Ilm Methonomi. 2018;4(2):145-59.

13. Simangunsong BA. Evolusi Saluran Interaksi di Era Internet. Komunikasi. 2011;1(3).

14. Straubhaar J, LaRose R. Media Now: Understanding Media, Culture and Technology. USA: Wadsworth Thomson Learning; 2011.

15. Triyono MB. Tantangan Revolusi Industri Ke 4 Bagi Pendidikan Vokasi. Semnasvotek. 2017;4:1-5.

16. Wahyuni D. Peningkatan Kompetensi Guru Menuju Era Revolusi Industri 4.0. Info Singk (Kajian Singk Terhadap Isu Aktual dan Strateg Pus Penelit Badan Keahlian DPR RI 2018. 2018;10(24).

\section{AUTHORS PROFILE}

Tubel Agusven obtained his S.T degree from the Islamic University of Indonesia in 2001 and M.M. from the University of Gadjah Mada, in 2003. Then currently as a Teaching Staff in the Management study program at STIE Pembangunan Tanjungpinang

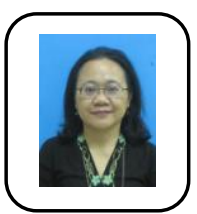

Helen Tan Sui Hong. Then currently as a Teaching Staff in the Management study program at Azman Hashim International Business School.

Satriadi obtained his S.AP degree from the STISIPOL Raja Haji Tanjungpinang in 2012 and M.Sc. from the University Teknologi Malaysia, in 2015. Then currently as a Teaching Staff in the Management study program at STIE Pembangunan Tanjungpinang. 